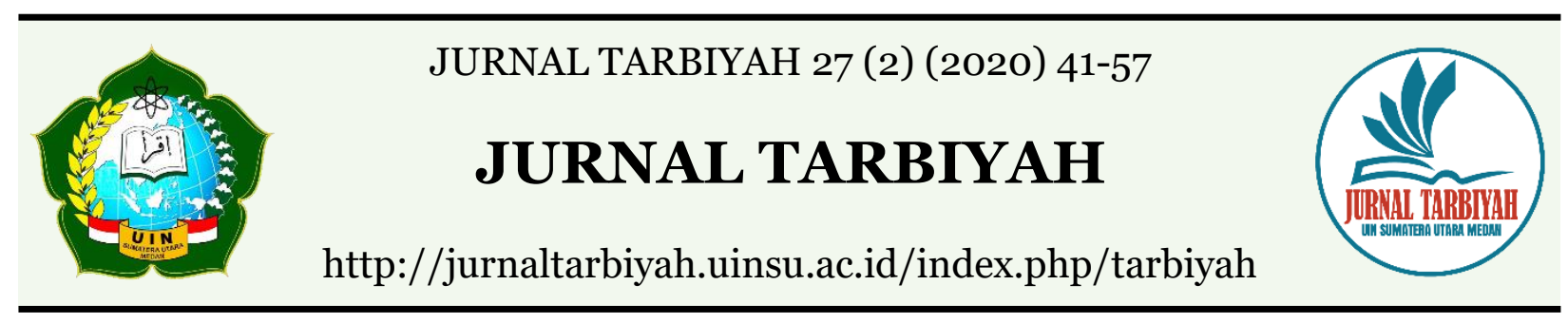

\title{
TEACHERS' PERCEPTIONS ON ADOPTING E-LEARNING DURING COVID-19 OUTBREAKS; ADVANTAGES, DISADVANTAGES, SUGGESTIONS
}

\author{
Balqis Husain'1, Yenita Natasya Idi², Megawati Basri3 $^{3}$ \\ 1,2,3 Universitas Pasifik Morotai, Pulau Morotai, Indonesia \\ Email: 1balqishusain.bh@gmail.com, 2yenitatasyaidi@gmail.com, \\ 3Megawatibasrio65@gmail.com
}

DOI : 10.30829/tar.v27i2.738

Accepted: July 26th, 2020. Approved: December 25th, 2020. Published: December 31th, 2020

\begin{abstract}
This study is to know the teachers' perception of adopting a virtual classroom during a pandemic and discover the conveniences, obstacles, and suggestions when e-learning is being carried out. Sort of this research was qualitative using descriptive method. The method of choosing respondents used convenience sampling. Data collection used questionnaires and open-ended questions. Junior and senior high school teachers in North Maluku were respondents in this research. The subjects of this study were 92 respondents. To analyze the data using SPSS 17 . Based on the finding, it found that majority of the teachers used several platforms for online home study during the lockdown. Either Single types of platforms or mixed e-learning was used to gain maximum results in instructional activity. Nine list advantages were addressed on elearning; in the contrary, it also produced seven barriers. Additionally, the educators offered attractive and innovative ideas to tackle numerous obstacles among educators, students, and educational institutions.
\end{abstract}

Keywords: Teachers' Perception, E-Learning, Advantages, Disadvantages, Suggestions, Covid-19 Outbreaks 
Balqis Husain, Yenita Natasya Idi, Megawati Basri / JURNAL TARBIYAH 27 (2) (2020) 41-57

\section{INTRODUCTION}

There is no doubt that technology and information play a fundamental role in the pandemic era. Since all education systems have been changed, one hundred percent of learning models apply electronic learning, either asynchronous or synchronous. Nowadays, the Indonesian government has announced new normal regulations to reduce people's movement during COVID-19 outbreaks. Even though new normal regulation has already been applied since the beginning of June 2020, the entire learning system still requires both students and teachers to study at home by utilizing electronic devices (Zhou et al., 2020).

The students and teachers recently implemented an E-learning class through a reliable platform (Talebian et al., 2014). Different systems of the learning process are provided by e-learning. It is the biggest reason why the e-learning industry grew vastly over the last decade (Sulisworo, Ishafit, et al., 2016). E- Learning's flexibility and availability ensure professional development in teaching-learning class (Shi, 2016). Its usage promotes the learners to learn without being limited by time and distance (Valentina \& Abaidoo Nelly, 2015; Verawardina et al., 2020). E-learning accommodates any lecture information that the internet can access (Saputra et al., 2017). The integration of curriculum and electronic devices is the principal purpose of education institutions adopting electronic learning platforms beyond the classroom (Al-Mubireek, 2019). Elearning is the newest attractive learning model that promotes dynamic learning approaches (Yusuf \& Ahmad Jihan, 2020). Dynamic learning covers synchronous and asynchronous learning classes; both learning classes have numerous usages such as tutorial media, props, and test tools. Those assist the educators in conveying the lectures and helping the students grab the materials quickly (Novantara \& Muhammad, 2018). Both synchronous and asynchronous learning accommodate learning based on the learners' needs and pursue their learning style (Verawardina et al., 2020). Dewi (2016) argues that one indicator that determines the learner's success in learning is instructional media utilization. However, the teachers are required to use any appropriate learning media appropriate to the students' needs. Indeed, the e-learning platform alters the learner's personality. By learning autonomously leads the students to be responsible for their learning. These kinds of learning build both self-confidence and self-knowledge (Nedeva \& Dimova, 2010).

Besides, various e-learning tools can be boosted the classroom atmosphere; those different platforms bring new learning experiences, for instance, Google-classroom, 
Balqis Husain, Yenita Natasya Idi, Megawati Basri / JURNAL TARBIYAH 27 (2) (2020) 41-57

Moodle, and Webex. Another suitable social tool also encourages the students to get any lectures anywhere and anytime as well as these virtual platforms are identified as a common platform: Whatsapp, Google-Meet, Instagram, Telegram, and Facebook (Yusuf \& Ahmad Jihan, 2020). Furthermore, the implementation of e-learning platforms needs concrete commitments from education practitioners. This new teaching-learning model demands soft skill proficiency and electronic equipment readiness (Yusuf \& Ahmad Jihan, 2020). Educators are expected can promote alteration in this learning model. Thus the entire material which is delivered by the educators should be covered innovatively and attractively. Besides, this learning environment can provoke the learner's perspective circumstantially. Based on the various reasons above, the teachers must cover multiple roles either as a facilitator, collaborator, mentor, trainer, director, or study partner (Verawardina et al., 2020).

Nowadays, most of the intermediate school teachers, junior high school, and senior high school at North Maluku find a new dilemma since the e-learning system is implemented during Corona Virus spreading. Unless most of the educators in Indonesia have adopted e-learning for over a few decades, in fact, in North Maluku, this learning system is rarely implemented, and it has fully implemented while the government announces to requires e-learning while lockdown. Since e-learning has been adopted over the institution, in particular educational institutions, a new dilemma is faced among the learners, educators, and parents. A takeover of the educators' role by parents is regarded as a substantial dilemma. The learners are required to study independently with parents are the newest prominent partner who takes control of learning sustainability rather than teachers (Zhou et al., 2020). Indeed, some technical problems are raised by Valentina \& Abaidoo Nelly (2015) whereas the availability of electronic device and worthiness internet access is the main requirements should be prepared before adopting e-learning class. The fundamental cases of implementing e-learning are poor internet access (Al Zumor et al., 2013). Besides, e-learning is considered does not cover entire disciplines. Indeed, the implementation of e-learning suits with discipline requires more theories than disciplines that demand any practical experiences (Talebian et al., 2014).

However, voice has raised concerns about the analysis and implementation of mixed instructional design with specific disciplines. This sort of instructional design integrates traditional learning and computer-based learning models (online and offline); this study has been conducted by (Kristiono et al., 2019; Dwiyogo \& Radjah, 2020; Sulisworo et al., 2016; Wahyuni, 2016; Al Zumor et al., 2013;). A prior study has analyzed, 
compared, as well as developed any appropriate multiform electronic tools with a purpose to create the easiness of the teaching-learning process (Abbasi et al., 2020; Al-Mubireek, 2019; Nurfalah, 2019; Shi, 2016; Sohibun \& Ade, 2017; Nedeva \&Dimova, 2010; Sohibun \& Ade, 2017;). Another study highlights the potential effect from various aspects of life when implementing E-Learning during Covid-19; this study has been carried out by (Sahu, 2020; Darmalaksana et al., 2020; Verawardina et al., 2020; Zhou et al., 2020; Khan, 2020).

To sum up, it is necessary to identify the teacher's perceptions about adopting any available e-learning platform during the Coronavirus disease deployment. It is interesting to know precisely any kind of barrier faced by e-learning users, how they survive to overcome this phenomenon, and what kind of solutions are offered.

\section{METHOD}

This study was conducted in North Maluku and spread through seven regions. The Seventh regions were Pulau Morotai, Ternate, Tidore Kepulauan, North Halmahera, Central Halmahera, West Halmahera, and South Halmahera. The type of this research was qualitative analysis using descriptive methods. The sampling method used to select respondents was the convenience sampling technique. The subjects of this research were 92 teachers at junior and senior high schools in North Maluku. The instrument used in this study was an open-ended questionnaire interview. The researcher utilized SPSS 17 for windows to analyze the data.

\section{RESULTS}

This chapter concerns the finding and some pertinent ideas that will be discussed in the discussion part. The result performs the respondent's demographics, validity, and reliability of the instruments, overview numerous items, and describe all indicators.

Table 1. Demographics of Respondents

\begin{tabular}{|c|c|c|}
\hline & Frequency & Valid Percent \\
\hline \multicolumn{3}{|c|}{ Respondent's Originate } \\
\hline Ternate & 22 & 23.9 \\
\hline Tidore Kepulauan & 2 & 2.2 \\
\hline Pulau Morotai & 46 & 50.0 \\
\hline
\end{tabular}


North Halmahera

West Halmahera

Central Halmahera

South Halmahera

\begin{tabular}{rr}
\hline 10 & 10.9 \\
\hline 4 & 4.3 \\
\hline 3 & 3.3 \\
\hline 5 & 5.4
\end{tabular}

Occupation

Teachers at Junior High School

Teachers at Senior High School

Discipline

\begin{tabular}{lrr}
\hline Science & 21 & 22.8 \\
\cline { 2 - 3 } Social & 15 & 16.3 \\
\cline { 2 - 3 } Language & 43 & 46.7 \\
\cline { 2 - 3 } Technology and Information & 2 & 2.2 \\
\cline { 2 - 3 } General Subjects & 11 & 12.0 \\
\cline { 2 - 3 }
\end{tabular}

The data show that the majority of respondents originated from seven districts. The most significant percentage was from Pulau Morotai, with $50.0 \%$ of respondents. The second from the greatest was Ternate, with $23.9 \%$ of respondents. The third from North Halmahera, with 10.9 \% of participants involved in the survey, South Halmahera as big as $5.4 \% \%$ of participants. West Halmahera, with as many as $4.3 \%$ of respondents, and there were $3.3 \%$ of Central Halmahera respondents. All of the respondents were categorized into junior high school and senior high school teachers. 40.2\% were junior high school teachers, and 59.8\% were senior high school teachers. All the teachers taught in various disciplines. The majority of respondents (46.7 percent) were from the language profession, 22.8 percent were from the science discipline, 16.3 percent were from the social field, 12.0 percent were from the general subject, and the rest (2.2 percent) were from the technology and information subject.

Table 2.Sorts of Platforms Adopted in E-Learning Class

\begin{tabular}{|c|c|c|}
\hline & Frequency & Valid Percent \\
\hline \multicolumn{3}{|c|}{ Sorts of Apps } \\
\hline Whatsapp & 13 & 14.1 \\
\hline Zoom & 6 & 6.5 \\
\hline Messenger & 16 & 17.4 \\
\hline
\end{tabular}


Balqis Husain, Yenita Natasya Idi, Megawati Basri / JURNAL TARBIYAH 27 (2) (2020) 41-57

Google Classroom

Line

Moodle

Email

Mixture Platforms

Did Not Apply any e-Learning

Total

\begin{tabular}{rr}
\hline 5 & 5.4 \\
\hline 5 & 5.4 \\
\hline 1 & 1.1 \\
\hline 1 & 1.1 \\
\hline 38 & 41.3 \\
\hline 7 & 7.6 \\
\hline 92 & 100.0
\end{tabular}

The list demonstrates that most teachers, either secondary or high school teachers, used numerous network learning platforms. Most of them prefer to use a combining platform, while this kind of platform reached a peak percentage of $41.3 \%$, on the other hand, 38 users used this type of platform. The other favorable platform was dominated by the Messenger app, with a maximum of 17.4 percent. Besides, 13 percent of users preferred to use Whatsapp software in continuing education classrooms, 6.5 percent of teachers did e-learning by trying to adopt the Zoom application. Simultaneously, the other tended to use both Google Classroom and Line with 5.5 percent, respectively, while the least devices implemented both Moodle and Email with 1.1 percent, respectively. Unfortunately, 7.6 percent of North Maluku teachers were identified did not pay close attention to e-learning. On the other hand, they did not apply any other kinds of electronic devices to support e-learning during the spreading of Corona Virus diseases.

Table 3. Categorization of Apps and the Users Proficiency on Soft-Skill

\begin{tabular}{|c|c|c|}
\hline & Frequency & Valid Percent \\
\hline \multicolumn{3}{|l|}{ Apps Classification } \\
\hline Single Platform & 47 & 51.1 \\
\hline Mixture Platforms & 38 & 41.3 \\
\hline Did Not Apply E-Learning & 7 & 7.6 \\
\hline \multicolumn{3}{|l|}{ Soft-skill proficiency } \\
\hline Limited user & 3 & $3 \cdot 3$ \\
\hline Modest user & 38 & 41.3 \\
\hline Competent user & 45 & 48.9 \\
\hline Expert user & 6 & 6.5 \\
\hline
\end{tabular}


The data indicate that 51.1 percent of users implement single platforms, including Whatsapp, Zoom, Messenger, Google Classroom, Line, Moodle, or Email. 41.3 percent of teachers used more than one platform or mixed platforms. It was found that the remaining portion (7.6 percent) did not perform e-learning or use any electronic device in instructional activities. Nevertheless, 48.9 percent of users were competent or very good to operate technology devices, $41.3 \%$ were classified as modest users, only 6.5\% were identified as experts to operate technical equipment, and $3.3 \%$ were grouped into limited users.

Table 4. Overview of Teacher's Perspective on Preparation of Education Institution in Adopting E-Learning

\begin{tabular}{lcccc}
\hline & \multicolumn{2}{c}{ Responses } & Mean & $\begin{array}{c}\text { Std. } \\
\text { Deviation }\end{array}$ \\
\hline Personal Electronic Tools & Yes & No & & \\
\hline Internet access problem & 89 & 3 & 1.03 & .179 \\
\hline $\begin{array}{l}\text { The utilization of e-learning before the } \\
\text { pandemic }\end{array}$ & 64 & 28 & 1.30 & .463 \\
\hline $\begin{array}{l}\text { Subsidy provides by the education } \\
\text { Institution }\end{array}$ & 16 & 59 & 1.64 & .482 \\
\hline $\begin{array}{l}\text { Asynchronous and synchronous } \\
\text { learning should be implemented even } \\
\text { though a pandemic has gone }\end{array}$ & 83 & 9 & 1.83 & .381 \\
\hline
\end{tabular}

The table shows that more than half of the participants (89) responded positively to personal electronic devices' ownership. Followed by 83 respondents who believed that both asynchronous and synchronous learning should be applied even though the pandemic had gone, and 64 subjects faced with any significant issues with internet access. In contrast, other areas had faulty internet connections. On the contrary, 76 teachers argued that most schools did not offer internet fees and found that 59 educators confirmed that e-learning never took place in the teaching classroom before the pandemic. The maximum mean was 2.83. The grant factor for academic institutions dominated it. 
Table 5. Validity Test

\begin{tabular}{lllll}
\hline Scale & Items number & $\begin{array}{l}\text { Valid Items } \\
\text { number }\end{array}$ & r table (5\%) & $\begin{array}{l}\text { Validities } \\
\text { Indexes }\end{array}$ \\
\hline $\begin{array}{l}\text { Questionnaire } \\
\text { items }\end{array}$ & 20 & 20 & 0.202 & $0.354-0.807$ \\
\hline
\end{tabular}

The table performs that all items were valid. The r-table with $5 \%$ was 0.202 to be lower than the correct item. The corrected item was a range from 0.354 to 0.807 .

Table 6. Reliability Test

Cronbach's Alpha

$\mathrm{N}$ of Items

.805

20

The table points out that Cronbach's Alpha value was 0.805, with the number of items was 20. All of the questionnaire items were categorized as consistent or reliable.

Table 7. Description of Knowledge Competencies Items

\begin{tabular}{lllll}
\hline & Minimum & Maximum & Mean & $\begin{array}{l}\text { Std } \\
\text { Deviation }\end{array}$ \\
\hline Science & 1 & 5 & 3.42 & .880 \\
\hline Social & 1 & 5 & 3.18 & .937 \\
\hline Language & 1 & 5 & 3.64 & .820 \\
\hline Technology and Information & 1 & 5 & 3.33 & .907 \\
\hline Total & 4 & 20 & & \\
\hline
\end{tabular}

These data were divided into four disciplines, and the overall average was 3.64. It can be said that most teachers focused on that e-learning can promote learning in language acquisitions.

Table 8. Description of Advantages Items

\begin{tabular}{llll}
\hline Minimum & Maximum & Mean & Std Deviation \\
\hline
\end{tabular}


Balqis Husain, Yenita Natasya Idi, Megawati Basri / JURNAL TARBIYAH 27 (2) (2020) 41-57

\begin{tabular}{lllll}
\hline Promoting Exhilaration & 1 & 5 & 3.00 & 1.069 \\
\hline Boost communication & 1 & 5 & 3.24 & .930 \\
\hline Effectiveness & 1 & 5 & 3.43 & .929 \\
\hline Attractive and fruitful & 1 & 5 & 3.66 & .829 \\
\hline Easy to catch the materials & 1 & 5 & 3.46 & .857 \\
\hline $\begin{array}{l}\text { Insightful particular in } \\
\text { technology proficiency }\end{array}$ & 1 & 5 & 3.96 & .725 \\
\hline Time efficiency & 1 & 5 & 3.53 & .907 \\
\hline Create interaction & 1 & 5 & 3.07 & .992 \\
\hline $\begin{array}{l}\text { Covered with authentic } \\
\text { materials }\end{array}$ & 1 & 5 & 3.45 & .894 \\
\hline Total & & & & \\
\hline
\end{tabular}

Based on the ninth list of the above benefits, the highest average was 3,96. It means that most respondents believed that electronic learning built awareness of ICT competence for educators and students. The lowest average was 3.07; e-learning was seen to pump up little engagement in both students and teachers.

Table 9. Description of Disadvantages Items

\begin{tabular}{lllll}
\hline & Minimum & Maximum & Mean & $\begin{array}{r}\text { Std } \\
\text { Deviation }\end{array}$ \\
\hline Boost Individualistic personality & 1 & 5 & 3.55 & .953 \\
\hline Promotes Anti-Social & 1 & 5 & 3.28 & 1.009 \\
\hline Difficult to operate e-learning & 1 & 5 & 2.40 & .984 \\
\hline Limited internet access & 1 & 5 & 4.15 & .851 \\
\hline $\begin{array}{l}\text { Should have a personal } \\
\text { electronic device }\end{array}$ & 1 & 5 & 3.99 & .908 \\
\hline $\begin{array}{l}\text { E-learning is regarded as } \\
\text { ineffective compare to }\end{array}$ & 1 & 5 & 3.04 & 1.026 \\
conventional learning & & & & \\
\hline Greater chance of cheating & 1 & 5 & 3.52 & 1.032 \\
\hline Total & 7 & 35 & 20.413 & 6.763 \\
\hline
\end{tabular}


Balqis Husain, Yenita Natasya Idi, Megawati Basri / JURNAL TARBIYAH 27 (2) (2020) 41-57

These data indicate that three metrics have been taken into consideration. It was found that the highest average of the three indicators above was 30.79 for the advantage indicators. The lowest mean was 14.28; it was addressed to the limitations indicators. While the introduction of e-learning had encouraged a range of challenges, it can be inferred that most teachers consider e-learning as having more benefits compared with restrictions.

Table 10. Teacher's Suggestions to Overcome E-learning's Obstacles

\begin{tabular}{cl}
\hline No & \\
\hline 1 & Equipment and infrastructures \\
\hline 2 & Subsidiary for internet fees provides by the institution \\
\hline 3 & Proper internet access \\
\hline 4 & Conducting training continuously for all academic members to increase their \\
& ICT proficiency \\
\hline 5 & Conducting Socialization to introduce e-learning systems \\
\hline 6 & Preparing various sources as an alternative way for overcoming poor internet \\
& access \\
\hline 7 & Building cooperation among parents, teachers, and students \\
\hline 8 & Boost the student's interest in order to be active on e-learning \\
\hline 9 & Provide extra time for e-learning class \\
\hline 10 & Develop any platforms or software for several disciplines that need more \\
\hline & practical experiences
\end{tabular}

Based on the respondents' ideas, it can be described that the main phenomena to be addressed were technical problems. Additionally, teachers offer some solutions to overcome some technical problems and students' less interest in online learning. For instance, establishing collaboration, and coordination among parents, teachers, and students were a solution to defeat the students' less interest in this learning. So, e-learning can operate successfully.

The research finding shows that almost all North Maluku teachers used a single platform to teach during lockdown due to Covid-19. Messenger machine was recognized as a suitable application for North Maluku students. Unfortunately, during the pandemic, several did not conduct virtual learning. Moreover, most teachers were found competent 
to operate digital equipment, specifically in teaching-learning activity, when they already had their electronic equipment. E-learning has been enforced throughout many areas for another few years. However, in this case, the researcher noticed that most North Maluku teachers implement a 100 percent e-learning system since the local Authority declared Large-Scale Social Restriction regulation. Although this kind of learning was seen as such a new model for North Maluku teachers, they were passionate about e-learning, although Corona Virus disease had gone. The key elements the educational institution should consider were free internet access.

Furthermore, based on the teachers' feedback, e-learning can increase students' knowledge in particular language discipline. This study defined nine lists of benefits. Teachers argued that e-learning encouraged teachers and students to raise more awareness of technology and information skills. Conversely, virtual learning produced seven obstacles. The key issue was limited internet access. However, this form of learning entails some challenges; most educators believed that this learning encouraged more conveniences than restriction. Furthermore, some useful and informative ideas were offered by the teachers to tackle this issue. For example, the institution should prepare maximally electronic facilities and infrastructures, grant extra internet access costs, establishing collaboration and coordination by many parents, teachers, and students so that e-learning can function appropriately.

Associate with study has been conducted by Abbasi et al. (2020), their study concerns to identify the student's perception in implementing e-learning at the private institution; they claim that despite its gain in Pakistan, digital technology has enormous popularity today, learners have not yet been accepted for teaching purposes. $77 \%$ of students are even more tempted to conventional teaching instead of E-teaching. Both administrators and faculty members should take the necessary measures to improve quality e-teaching and improve their learning activity during locked down. Both preparation and clear steps are fundamentals actions that are needed in applying online learning. It is crucial to maximizing online learning to increase learning effectiveness (Verawardina et al., 2020).

On the contrary, in his study, Shi (2016) tries to implement e-learning in reading and translation classrooms. His finding shows that students become more interested in the subject, engaging more frequently with teachers and their colleagues via the online chat room or discussion board. Barakati (2013) proves that electronic pieces of equipment promote various impacts on EFL class. It boosts communication, encouragement, 
Balqis Husain, Yenita Natasya Idi, Megawati Basri / JURNAL TARBIYAH 27 (2) (2020) 41-57

reinforcement. Instead, technologies enhance the student's language acquisition. This technique can promote better insight and make an efficient, effective, and educative attraction (Dwiyogo \& Radjah, 2020). Furthermore, Hartanto (2016) declares that elearning promotes some of the logical implications. Such learners can freely take resources from any location or space; students can efficiently study the topics they are interested in and communicate to experts; learning material can easily take in any corner of the world, regardless of where they study. Nevertheless, opportunities were also faced with cost issues, technology readiness, community support, and e-learning regulations. Ninety-five percent of the standard of education can be achieved through information technology (Nedeva \& Dimova, 2010).

In this study, the Facebook Messenger machine is recognized as a suitable application for North Maluku students. Social Media is a medium that offers an opportunity as well as a challenge for educators to develop lectures that are more attractive, obvious, attractive, and meaningful. Students are considered not focused on the internet's huge cost (Nurkhin \& Fachrurrozie, 2018). The education performance of ICTs depends on how and for what purposes they are used. Like any other educational device, ICTs do not function in the same way for everybody and anywhere (Talebian et al., 2014). Another previous study has been carried out by Suliswati \& Sari (2019). Their study reveals a significant effect on the student's learning outcome by adopting the Facebook Messenger app to the Physics classroom. Wijaya et al., (2018) focus on Chanel Chat-board has developed installed on the Facebook Fan-Page Messenger. This elearning model assists the teacher's role in presenting materials and item questioning on the student's score-based skills. Conversely, Darmalaksana et al., (2020) said that most students tend to use Whatsapp devices in virtual classrooms rather than Facebook Messenger. It is believed to encourage effectiveness and enhance students' critical thinking (Kartikawati \& Pratama, 2017).

Furthermore, several ideas are offered to overcome various phenomena that occurred when adopting e-learning during the spreading of Covid-19. For instance, the institution should prepare maximally electronic facilities and infrastructures. Grant extra internet access costs; establish collaboration and coordination by many parents, teachers, and students; Boost the student's interest in e-learning, provide any resources; Provide extra-time; Develop any platform or software for several disciplines that need more practical experiences; and conduct training and socialization continuously for all academic members to increase their ICT proficiency. The Authority intends to begin 
socializing all regulatory requirements through the education and competence of teachers. To build the knowledge of teachers so that they also strengthen their skills through workshops, training upgrades, and independent learning to enhance their teaching quality (Sulisworo, Nasir, et al., 2016). Essentially, e-learning can improve students' understanding and learning outcomes, but this learning seems to be inefficient due to internet budget limits. The role of government is indeed significant, particularly in the procurement of facilities and infrastructure to support its e-learning process (Endah Wulantina, 2019). Since the pandemic era, home education and school education are more strongly connected through digital learning. It is the issue that is addressed in online education (Zhou et al., 2020).

\section{CONCLUSION}

Since the Corona Virus spreading, the local government starts to implement Large- Scale Social restriction regulation. Automatically, all of the schools at North Maluku are a force to implement e-learning $100 \%$. Based on the finding, it found that the majority of the teachers use several platforms for online home study during the lockdown. Either Single types of platforms or mixed e-learning is used to gain maximum results in instructional activity. Nine list advantages are addressed on e-learning; in the contrary, it also produces seven barriers. Additionally, attractive and innovative ideas are offered by the educators in order to tackle numerous obstacles faced by among educators, students, as well as an educational institution.

This current research is a reference for the authority to pay close attention to educational institutions' fundamental issues when implementing e-learning. Insufficient amenities and infrastructure of technology and poor internet access promote the student's outcome, and the learning process does not run maximally. On the other hand, since implementing e learning in reducing the students' movement, e-learning can stimulate student's interest to become more active in this virtual class. Besides, it establishes good coopee-learningng teachers, students, and parents. This research result can contribute to another future researcher who wants to research similar research with various variables.

\section{REFERENCES}

Abbasi, S., Ayoob, T., Malik, A., \& Memon, S. I. (2020). Perceptions of Students Regarding E-learning During Covid-19 at a Private Medical College. Pakistan 
Balqis Husain, Yenita Natasya Idi, Megawati Basri / JURNAL TARBIYAH 27 (2) (2020) 41-57

Journal of Medical Sciences, 36(COVID19-S4), 2-6.

https://doi.org/10.12669/pjms.36.covid19-s4.2766

Al-Mubireek, S. (2019). E-learning in the English Classroom: Comparing Two E-

Learning Platforms Impacting Preparatory Year Students' Language Learning. Call-

Ej, 2O(2), 19-37. http://callej.org/journal/20-2/Al-Mubireek2019.pdf

Al Zumor, A. W. Q., Al Refaai, I. K., Bader Eddin, E. A., \& Aziz Al-Rahman, F. H. (2013).

EFL students' Perceptions of A Blended Learning Environment: Advantages,

Limitations and suggestions for Improvement. English Language Teaching, 6(10),

95-110. https://doi.org/10.5539/elt.v6n10p95

Barakati, D. P. (2013). Dampak Penggunaan Smartphone dalam Pembelajaran Bahasa

Inggris (Persepsi Mahasiswa). Jurnal Elektronik Fakultas Sastra Universitas Sam

Ratulangi, 1(1), 1-13.

https://ejournal.unsrat.ac.id/index.php/jefs/article/view/1820

Darmalaksana, W., Hambali, R. Y. A., Masrur, A., \& Muhlas. (2020). Analisis

Pembelajaran Online Masa WFH Pandemic Covid-19 sebagai Tantangan Pemimpin

Digital Abad 21. Karya Tulis Ilmiah (KTI) Masa Work From Home (WFH) Covid-

19 UIN Sunan Gunung Djati Bandung Tahun 2O2O, 1(1), 1-12.

http://digilib.uinsgd.ac.id/30434/

Dewi, S. V. (2016). Efektivitas Penggunaan Media Screencast O-Matic pada Mata Kuliah Kalkulus Integral terhadap Hasil Belajar Mahasiswa. Jurnal Penelitian Pendidikan Dan Pengajaran Matematika, 2(1), 61-66.

http://jurnal.unsil.ac.id/index.php/jp3m/article/view/157

Dwiyogo, W. D., \& Radjah, C. L. (2020). Effectiveness, Efficiency and Instruction

Appeal of Blended Learning Model. International Journal of Online and

Biomedical Engineering, 16(4), 91-108. https://doi.org/10.3991/ijoe.v16io4.13389

Endah Wulantina, S. M. (2019). Persepsi Peserta Didik terhadap Metode Blended

Learning dengan Google Classroom. Jurnal Inovasi Matematika, 1(2), 110-121.

https://doi.org/10.35438/inomatika.v1i2.156

Hartanto, W. (2016). Penggunaan E-Learning Sebagai Media Pembelajaran. Jurnal

Pendidikan Ekonomi, 10(1), 1-18.

https://jurnal.unej.ac.id/index.php/JPE/article/view/3438

Kartikawati, S., \& Pratama, H. (2017). Pengaruh Penggunaan WhatsApp Messenger

Sebagai Mobile Learning Terintegrasi Metode Group Investigation Terhadap

Kemampuan Berpikir Kritis. Jupiter (Jurnal Pendidikan Teknik Elektro), 2(2), 33. 
Balqis Husain, Yenita Natasya Idi, Megawati Basri / JURNAL TARBIYAH 27 (2) (2020) 41-57 https://doi.org/10.25273/jupiter.v2i2.1797

Khan, I. A. (2020). Electronic Learning Management System : Relevance, Challenges and Preparedness. Journal of Emerging Technologies and Innovative Research ((JETIR), 7(5), 471-480.

https://d1wqtxts1xzle7.cloudfront.net/63286717/JETIR200507220200512-324001ynnf6.pdf?1589300548=\&response-content-

disposition=inline\%3B+filename\%3DElectronic_Learning_Management_System_ Re.pdf\&Expires $=1594297267 \&$ Signature $=$ cfutSdRoGOHnrWs3p1RLwnHqsXoisizD7

Kristiono, I. D., Dwiyogo, W. D., \& Hariadi, I. (2019). Pembelajaran Ilmu Gizi Olahraga Berbasis Blended Learning pada Mahasiswa Pendidikan Jasmani, Kesehatan, dan Rekreasi. Jurnal Pendidikan: Teori, Penelitian, Dan Pengembangan, 4(2), 235241. https://doi.org/http://dx.doi.org/10.17977/jptpp.v4i2.12004

Nedeva, V., \& Dimova, E. (2010). Some Advantages of E-Learning in English Language Training. Trakia Journal of Sciences, 8(8), 21-28. http://www.uni-sz.bg

Novantara, P., \& Muhammad, A. (2018). Implementasi E-Learning Berbasis Virtual Class dengan Menggunakan Metode Synchronous Learning pada Pembelajaran di Universitas Kuningan. Jurnal Ilmiah Teknik Informatika, 4(1), 1-7.

https://doi.org/https://doi.org/10.25134/buffer.v4i1.1290

Nurfalah, E. (2019). Optimalisasi E-Learning berbasis Virtual Class dengan Google Classroom sebagai Media Pembelajaran Fisika. Physics Education Research Journal, 1(1), 46-55. https://doi.org/10.21580/perj.2019.1.1.3977

Nurkhin, A., \& Fachrurrozie. (2018). Pemanfaatan Media Sosial untuk Pembelajaran Akuntansi di Perguruan Tinggi; Studi Empiris di Universitas Negeri Semarang. Seminar Nasional Pendidikan, 1-10.

https://publikasiilmiah.ums.ac.id/xmlui/handle/11617/10237

Sahu, P. (2020). Closure of Universities Due to Coronavirus Disease 2019 (COVID-19):

Impact on Education and Mental Health of Students and Academic Staff. Cureus, 2019(4), 4-9. https://doi.org/10.7759/cureus.7541

Saputra, A. S., Kusumawardani, S. S., \& Nugroho, E. (2017). Pengembangan Model Awal Sistem Evaluasi Penerimaan Pengguna E-Learning Janabadra. Prociding SENIATI $2017(B O O K-1), 1(\mathrm{~B} 3), 1-6$.

https://ejournal.itn.ac.id/index.php/seniati/article/view/1616

Shi, X. (2016). A comparative Study of E-Learning Platform in Reading and Translating 
Balqis Husain, Yenita Natasya Idi, Megawati Basri / JURNAL TARBIYAH 27 (2) (2020) 41-57

Course for Engineering Students. International Journal of Emerging Technologies in Learning, 11(4), 120-125. https://doi.org/10.3991/ijet.v11io4.5551

Sohibun, S., \& Ade, F. Y. (2017). Pengembangan Media Pembelajaran Berbasis Virtual Class Berbantuan Google Drive. Tadris: Jurnal Keguruan Dan Ilmu Tarbiyah, 2(2), 121. https://doi.org/10.24042/tadris.v2i2.2177

Suliswati, S., \& Sari, I. W. (2019). Pembelajaran Fisika Berbantukan Media Sosial Facebook dan Dampaknya Terhadap Hasil Belajar Fisika. Jurnal Pendidikan Fisika, 7(1), 1-14. https://doi.org/http://dx.doi.org/10.24127/jpf.v7i1.1788

Sulisworo, D., Ishafit, \& Firdausy, K. (2016). The Development of Mobile Learning Application Using Jigsaw Technique. International Journal of Interactive Mobile Technologies, 1O(3), 11-16. https://doi.org/10.3991/ijim.v10i3.5268 Sulisworo, D., Nasir, R., \& Maryani, I. (2016). Identification of Teachers' Problems in Indonesia on Facing Global Community. International Journal of Research Studies in Education, 6(2), 81-90. https://doi.org/10.5861/ijrse.2016.1519

Talebian, S., Mohammadi, H. M., \& Rezvanfar, A. (2014). Information and Communication Technology (ICT) in Higher Education: Advantages, Disadvantages, Conveniences and Limitations of Applying E-learning to Agricultural Students in Iran. Procedia - Social and Behavioral Sciences, 152, 300305. https://doi.org/10.1016/j.sbspro.2014.09.199

Valentina, A., \& Abaidoo Nelly. (2015). The Role of E-Learning, Advantages and Disadvantages of Its Adoption Inhigher Education. International Journal of Instructional Technology and Distance Learning, 12(1), 29-42. http://itdl.org/Journal/Jan_15/Jan15.pdf\#page=7

Verawardina, U., Asnur, L., Lubis, A. L., Hendriyani, Y., Ramadhani, D., Dewi, I. P., Darni, R., Betri, T. J., Susanti, W., \& Sriwahyuni, T. (2020). Reviewing online learning facing the Covid-19 outbreak. Talent Development and Excellence, 12(SpecialIssue3), 385-392.

http://www.iratde.com/index.php/jtde/article/view/281

Wahyuni, F. A. (2016). Blended Learning : Dua Metode ( Synchronous and Asynchronous ) Untuk Matakuliah Writing Materi Argumentative Essay. Journal2.Um.Ac.Id/Index.Php/Jinotep/Article/Download/2379/1431, 3,(No 2 P. 137), 137-143. https://doi.org/http://dx.doi.org/10.17977/umo31v3i22017p137 Wijaya, M. H., Sarosa, M., \& Tolle, H. (2018). Rancang Bangun Chatbot Pembelajaran Java pada Google Classroom dan Facebook Messenger. Jurnal Teknologi Informasi 
Balqis Husain, Yenita Natasya Idi, Megawati Basri / JURNAL TARBIYAH 27 (2) (2020) 41-57

Dan Ilmu Komputer, 5(3), 287. https://doi.org/10.25126/jtiik.201853837

Yusuf, B. N., \& Ahmad Jihan. (2020). Are We Prepared Enough? a Case Study of Challenges in Online Learning in a Private Higher Learning Institution During the Covid-19 Outbreaks. Advances in Social Sciences Research Journal, 7(5), 205-212. https://doi.org/10.14738/assrj.75.8211

Zhou, L., Wu, S., Zhou, M., \& Li, F. (2020). 'School's Out, But Class' On', The Largest Online Education in the World Today: Taking China's Practical Exploration During The COVID-19 Epidemic Prevention and Control As an Example. SSRN Electronic Journal, 4(2), 501-519. https://doi.org/10.2139/ssrn.3555520 